\title{
Analisis Kekuatan dan Re-design Box Body Mobil Pick-up Multiguna Pedesaan akibat Gaya Angin, Inersia, dan Sentrifugal
}

\author{
Maulika G. Jaisyah dan Julendra B. Ariatedja \\ Departemen Teknik Mesin, Fakultas Teknologi Industri, Institut Teknologi Sepuluh Nopember (ITS) \\ e-mail: ariatedja@me.its.ac.id
}

\begin{abstract}
Abstrak-Departemen Teknik Mesin ITS dipercayai oleh KEMENRISTEK untuk mengembangkan mobil pick-up multiguna pedesaan dan saat ini sudah sampai tahap finishing prototype yang kedua. Mobil ini memiliki empat fungsi dimana dua diantaranya menggunakan bagian box. Bagian ini hingga rancangan prototype mobil yang kedua belum dilakukan analisis kekuatan terhadap massanya. Kondisi tersebut menjadi latar belakang dilakukan analisis pada penelitian ini. Penelitian ini menggunakan metode elemen hingga dengan bantuan perangkat lunak berbasis Metode Elemen Hingga (MEH). Pembebanan yang dilakukan adalah beban akibat gaya angin, inersia sentrifugal maupun muatan. Hasil yang didapatkan adalah baik desain box pertama dan kedua ketika diberikan muatan penuh $2000 \mathrm{~kg}$ memiliki tegangan von misses yang melebihi tegangan yield material. Tegangan von misses terbesar terjadi saat mobil dikendarai berbelok, yaitu sebesar 348,69 Mpa dengan deformasi maksimum 8,357 mm dan safety factor 0,63 . Berdasarkan analisis ini dilakukan re-design dengan mengganti material pada beberapa bagian box dan modifikasi geometri kerangka box. Hasil yang didapatkan menjadi lebih aman dengan tegangan von misses sebesar 108,01 Mpa, deformasi maksimum 1,0892 mm dan safety factor 2,04 .
\end{abstract}

Kata Kunci-Deformasi maksimum, metode elemen hingga, pembebanan, struktur box mobil, tegangan von misses.

\section{PENDAHULUAN}

S Temenjak tahun 2011 Departemen Teknik Mesin ITS dipercayai oleh KEMENRISTEK untuk mengembangkan mobil pick-up multiguna pedesaan guna membantu masyarakat pedesaan khususnya dalam mengangkut penumpang, mengangkut hasil panen atau barang, kegiatan niaga, dan untuk mesin penggiling padi serta mesin pemarut kelapa. Pada tahun 2013, proses pengembangan pertama prototype mobil tersebut dilakukan oleh pihak Departemen Teknik Mesin ITS yang bekerja sama dengan perusahaan PT INKA dan PT Karya Tugas Anda [1].

Desain prototype box yang pertama menggunakan material mild steel. Massa total box body sebesar $700 \mathrm{~kg}$. Massa tersebut menjadi bahan evaluasi karena mesin yang digunakan pada mobil tidak besar, $650 \mathrm{cc}$, sehingga untuk menunjukkan performa kerja yang baik dibutuhkan beban body yang ringan baik pada body mobil maupun body box. Hal inilah yang menjadi alasan dilakukan pengembangan desain yang kedua pada tahun 2017 terhadap prototype box. Hal ini bertujuan untuk menurunkan massa box. Konsep baru yang dikembangkan untuk mengurangi massa box adalah dengan cara mengganti material box.
Desain box body yang kedua menggunakan material komposit fiber glass. Meski hanya bagian lapisan terluar saja yang diganti menggunakan komposit fiber glass sedangkan bagian kerangka tetap sama, yaitu ASTM A36 Steel dan bagian lapisan dalam tetap dengan mild steel. Berdasarkan hasil rancangan prototype box kedua yang dilakukan oleh PT Karya Tugas terjadi perubahan positif dari segi massa box body beserta kerangka box, yaitu massa total menjadi $415 \mathrm{~kg}$. Penurunan massa yang terjadi cukup besar sekitar 59\%.

Kedua rancangan box body yang digunakan untuk mobil pedesaan hingga saat ini belum memiliki analisis yang menghasilkan rasio kekuatan terhadap massa box tersebut. Sehingga belum dapat dipastikan seberapa besar pengaruh perubahan massa material box terhadap kekuatannya terutama pada kondisi pembebanan dinamis.

Oleh karena itu, diperlukan adanya analisis pengaruh rasio kekuatan terhadap massa box yang lama dan baru untuk didapatkan perbandingan sifat kekuatan antara kedua desain. Analisis yang akan dilakukan berdasarkan pembebanan dinamis dengan pendekatan statis pada simulasi. Permodelan sistem menggunakan perangkat lunak berbasis metode elemen hingga (MEH) dengan beberapa metode pembebanan yang mewakili kondisi nyata. Hal ini guna menjadi bahan pertimbangan dalam pengembangan prototype box yang selanjutnya agar menjadi lebih optimum, baik dari segi massa maupun kekuatan.

\section{METODE PENELITIAN}

\section{A. Prosedur Penelitian}

Tahapan dalam prosedur pada penelitian ini adalah sebagai berikut :

1. Mengumpulan data spesifikasi mobil multiguna,

2. Menghitung besar pembebanan sebagai parameter input,

3. Merancang 3D modelling pada perangkat lunak berbasis CAD dimana box terdiri dari 3 bagian utama, yaitu bagian dalam, kerangka dan bagian luar,

4. Simulasi analisis menggunakan perangkat lunak MEH,

5. Melakukan tes konvergensi,

6. Melakukan verifikasi dengan perhitungan gaya reaksi secara manual,

7. Membandingkan hasil analisis box pertama dan kedua,

8. Melakukan re-design dan analisis pada box ketiga. 


\section{B. Perhitungan Beban pada Tahap Prosedur secara Detail}

Perhitungan beban yang dilakukan berdasarkan analisis yang telah dilakukan oleh beberapa peneliti [2] dan [3] mengenai static structural menggunakan finite element method. Berikut ini adalah beberapa persamaan yang digunakan :

1. Beban akibat gaya $\operatorname{drag}\left(\mathrm{D}_{\mathrm{A}}\right)[4]$

$$
D_{A}=1 / 2 \cdot \rho \cdot V_{w k^{2}} \cdot C_{D} \cdot A
$$

2. Beban akibat muatan (W) [3]

$$
W=\Sigma m \cdot g \cdot k
$$

3. Beban akibat gaya inersia $\left(\mathrm{F}_{\mathrm{i}}\right)[3]$

$$
F_{i}=\Sigma m \cdot a \cdot k
$$

4. Beban akibat gaya sentrifugal (lateral) $\left(F_{\text {lat }}\right)$ [3]

$$
F_{\text {lat }}=\frac{\Sigma m \cdot v^{2}}{R} \cdot k \text {. }
$$

Keterangan :

$$
\rho \quad=\text { Massa jenis udara }=1,217 \mathrm{~kg} / \mathrm{m}^{3}[4]
$$

$\mathrm{V}_{\mathrm{wk}}{ }^{2}=$ Kecepatan relatif box terhadap angin $=22,17 \mathrm{~m} / \mathrm{s}$

$\mathrm{C}_{\mathrm{D}} \quad=$ Koefisien drag $=0,5957$ [5]

$\mathrm{A}=$ Frontal area box $=2,385 \mathrm{~m}^{2}$

$\Sigma \mathrm{m}=$ Massa box dengan muatan, $2700 \mathrm{~kg}$ (box pertama) dan $2415 \mathrm{~kg}$ (box kedua)

$\mathrm{g}=$ Percepatan gravitasi $\left(\mathrm{m} / \mathrm{s}^{2}\right)$

$\mathrm{k}=$ Faktor beban dinamis

$\mathrm{v} \quad=$ Kecepatan mobil saat berbelok $=6,7 \mathrm{~m} / \mathrm{s} \mathrm{[6]}$

$\mathrm{R} \quad=$ Radius belok $\quad=14,33 \mathrm{~m} \mathrm{[6]}$

Besarnya nilai $\mathrm{k}$ berbeda-beda di setiap perhitungan bergantung pada jenis pembebanan yang dilakukan. Pada perhitungan muatan besarnya nilai $\mathrm{k}=3$. Pada gaya inersia, $\mathrm{k}$ $=0,75$. Pada gaya sentrifugal, $\mathrm{k}=1,4[3]$.

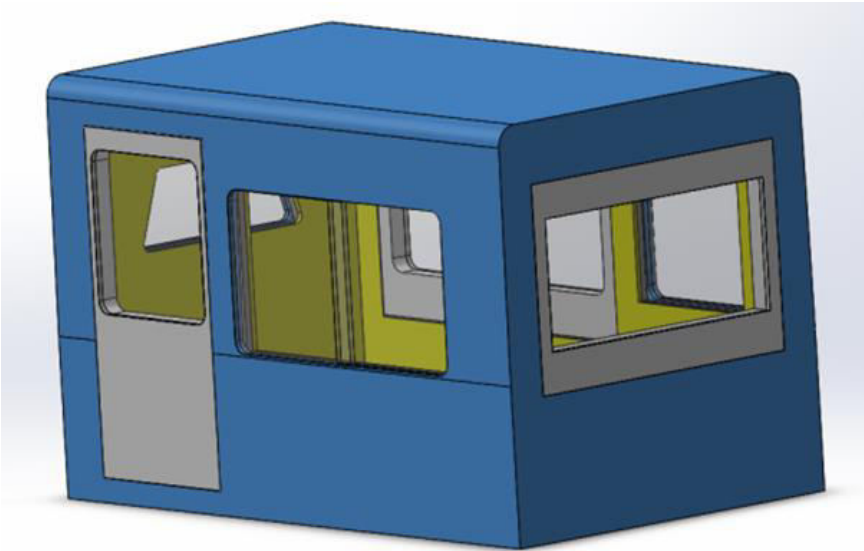

Gambar 1. Rancangan 3D modelling pada software CAD

\section{Hipotesis Penelitian}

Hipotesis dilakukan guna mengefisiensikan waktu dengan tetap mendapatkan hasil analisis yang diinginkan. Terdapat 2 hipotesis pada penelitian ini, yaitu :

1. Efisiensi waktu dilakukan dengan cara analisis hanya pada saat pengereman dan berbelok saja dengan mempertimbangkan besarnya gaya inersia pengereman dan gaya sentrifugal akibat belok yang dihasilkan dari perhitungan beban.

2. Pada tahap re-design bagian dari box yang akan dilakukan modifikasi adalah kerangka dan bagian dalam box untuk mengurangi massa total box.

\section{Prosedur Detail dalam Analisis Simulasi}

Tahapan dalam prosedur analisis pada software MEH secara detail adalah sebagai berikut :

1. Memasukkan material properties pada engineering data tool,

2. Memasukkan geometri 3D modelling ke dalam perangkat lunak MEH,

3. Melakukan meshing pada setiap bagian box menggunakan jenis solid meshing 186 dan 187,

4. Memasukkan pembebanan dan kondisi batas,

5. Mengatur parameter solusi berupa tegangan von misses dan deformasi total,

6. Melakukan running simulasi dan mendapatkan hasil.

Tabel 1.

Nilai pembebanan yang digunakan sebagai input

\begin{tabular}{ccc}
\hline \hline No. & Beban & Besarnya (N) \\
\hline 1 & Muatan & 58860 \\
2 & Drag & 424,91 \\
3 & Inersia pengereman \\
box pertama & 3898,125 \\
4 & Inersia pengereman \\
box kedua & 3486,656 \\
5 & Sentrifugal box & pertama \\
& Sentrifugal box kedua & 11841,186 \\
6 &
\end{tabular}

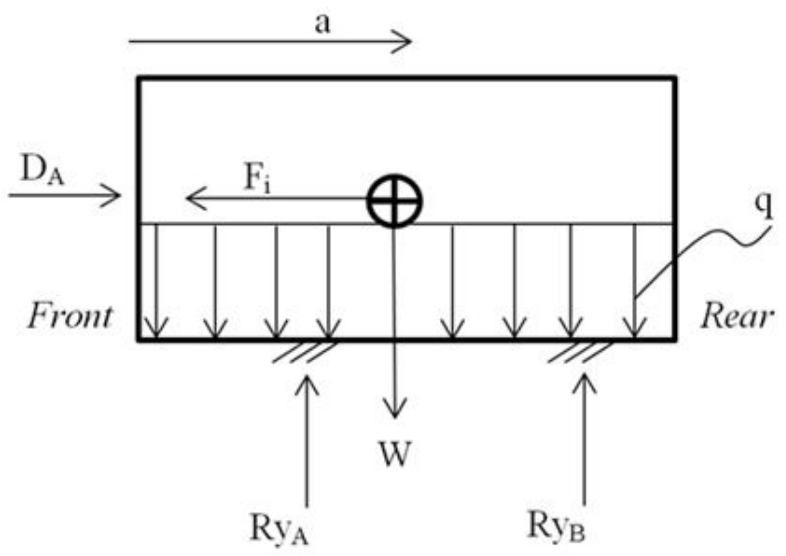

Gambar 2. Free Body Diagram box tampak samping secara 2D saat mengalami pengereman

Keterangan :

$\mathrm{D}_{\mathrm{A}} \quad=$ Gaya drag (angin)

$\mathrm{q}=$ Muatan

$\mathrm{Ry}_{\mathrm{A}}=$ Gaya reaksi di titik A

$\mathrm{Ry}_{\mathrm{B}}=$ Gaya reaksi di titik B

$\mathrm{W}=$ Berat box 


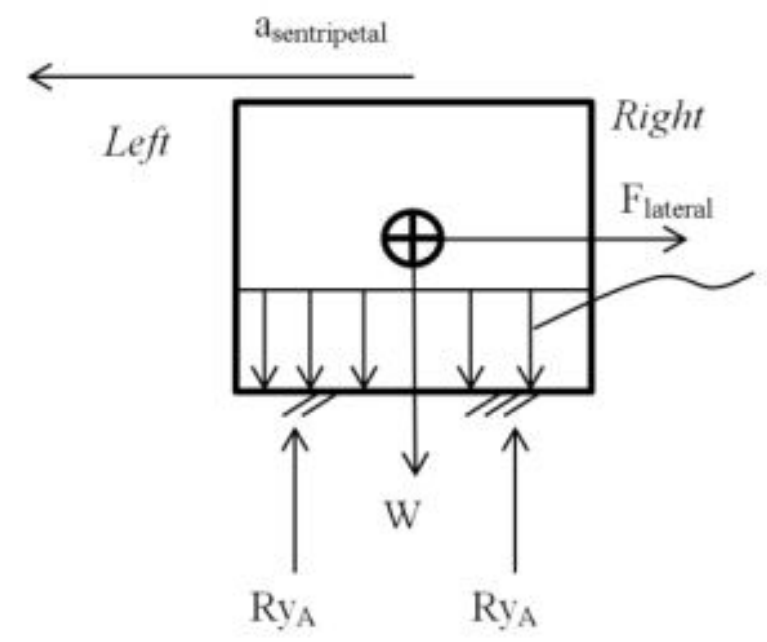

Gambar 3. Free Body Diagram box saat mengalami belok tampak depan

Keterangan :

$$
\mathrm{a}_{\mathrm{s}} \quad=\text { Percepatam sentripetal }
$$$$
\mathrm{F}_{\text {lateral }}=\text { Gaya lateral }
$$

\section{HASIL DAN PEMBAHASAN}

\section{A. Hasil Analisis Pengereman Box Pertama}

Gambar 4.(a) merupakan gambaran hasil analisis mengenai bagian box yang mengalami tegangan von misses maksimum. Hasil dari analisis menunjukkan bahwa besar tegangan von misses sebesar 308,76 Mpa. Tegangan tersebut berada di alas bawah box bagian dalam dimana bagian tersebut adalah bagian yang berdekatan dengan sisi kerangka dibawahnya. Kontak yang terjadi antara kedua bagian menimbulkan tegangan sebagai reaksi dari muatan di atas dan adanya penahan berupa kerangka di bagian bawah. Besarnya tegangan di area tersebut menjadi maksimum disebabkan karena beban muatan penuh yang sangat besar mencapai $58860 \mathrm{~N}$, sehingga tegangan terfokus pada area tersebut.

Pada gambar 5.(a) menunjukkan besar deformasi maksimum yang terjadi pada saat dilakukan pembebanan pengereman. Deformasi maksimal terjadi sebesar 7,9386 mm pada alas bawah box bagian dalam dimana bagian tersebut adalah bagian yang tidak mengalami kontak langsung dengan kerangka dibawahnya bahkan cenderung berada paling jauh dari kerangka. Akibat tidak adanya kerangka yang menahan bagian tersebut dan beban muatan yang diberikan sangat besar mengakibatkan terjadi deformasi yang cukup besar. Pada gambar diatas tergambar dengan jelas cekungan akibat deformasi dengan perbesaran skala 22 kali (auto scale) lebih besar dari kondisi sebenarnya oleh MEH. Semua cekungan akibat deformasi yang terjadi berada pada bagian yang tidak ditahan oleh kerangka. Besarnya safety factor adalah 0,633.

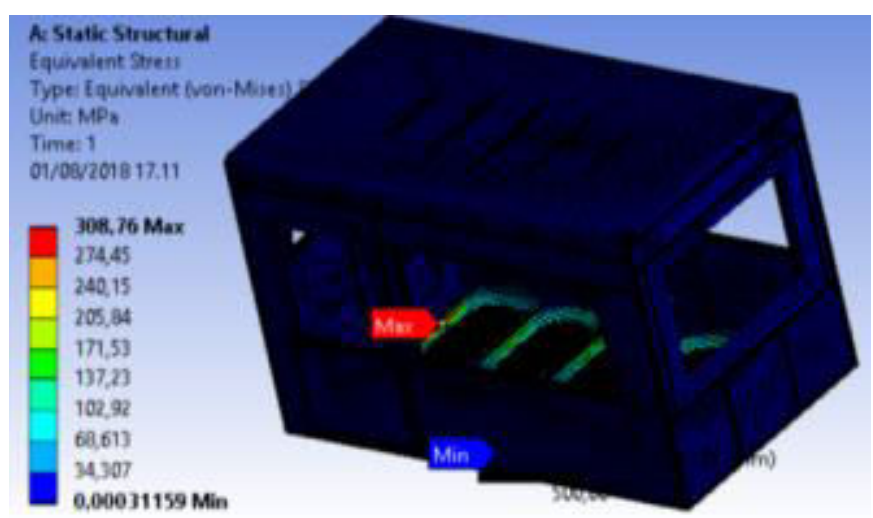

(a)

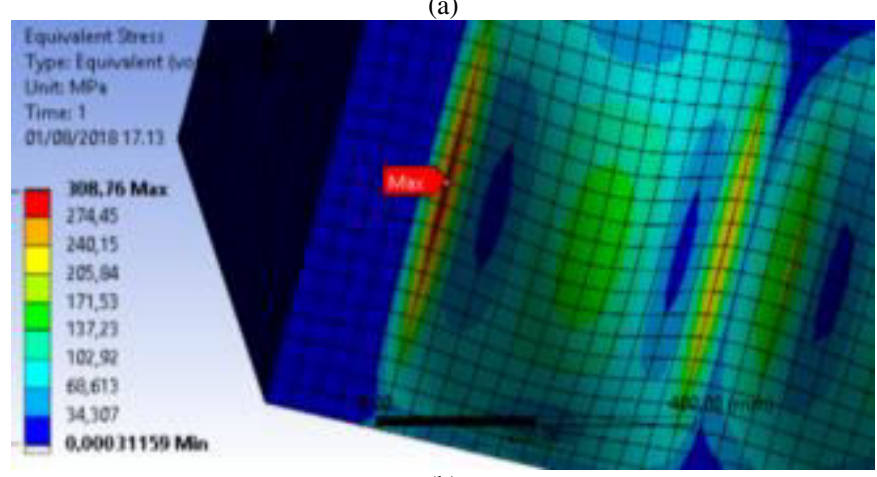

(b)

Gambar. 4. (a) Lokasi tegangan von misses maksimum hasil tes konvergensi pada box body utuh pertama ketika mengalami pengereman dengan muatan penuh, (b)Tampilan detail tegangan von misses maksimum.

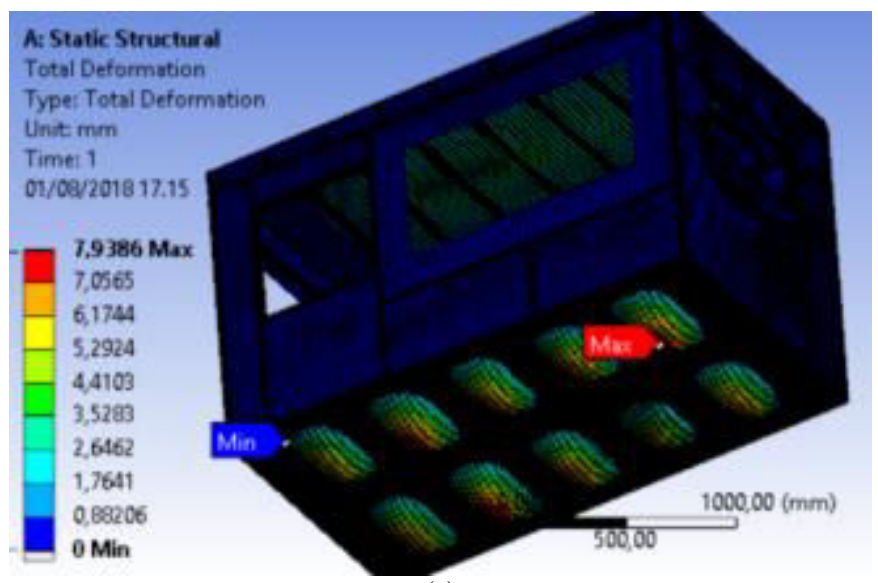

(a)

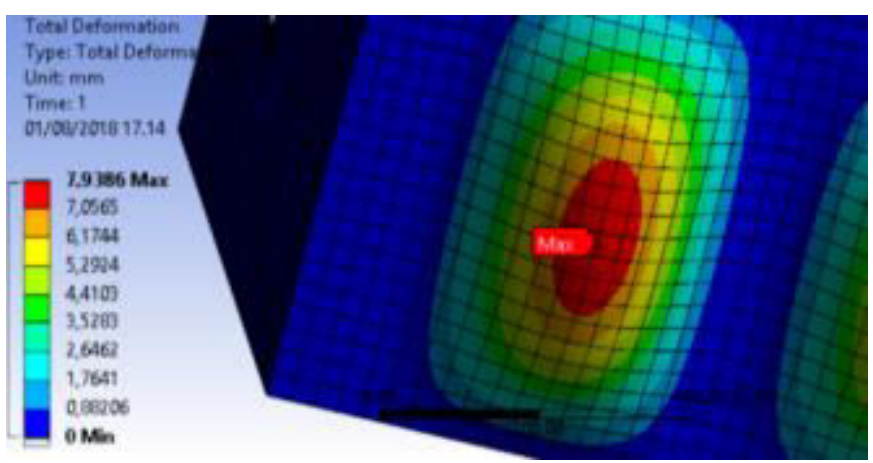

(b)

Gambar. 5. (a) Lokasi deformasi maksimum hasil tes konvergensi pada box body utuh pertama ketika mengalami pengereman dengan muatan penuh, (b)Tampilan detail deformasi maksimum. 


\section{B. Hasil Analisis Belok Box Pertama}

Pada gambar 6.(a) menunjukkan hasil tegangan von misses sebesar 310,09 Mpa. Tegangan tersebut berada di part yang sama saat mengalami kondisi pengereman, di alas bawah box bagian dalam. Beban akibat muatan masih menjadi penyebab terjadinya tegangan von misses maksimum, sehingga pengaruh gaya sentrifugal tidak mendominasi.

Gambar 6.(b) dengan skala 22 kali menunjukkan besar deformasi maksimum yang terjadi pada saat dilakukan pembebanan pengereman. Deformasi maksimal terjadi sebesar 7,9959 mm pada alas bawah box bagian dalam dimana bagian tersebut adalah bagian yang tidak mengalami kontak langsung dengan kerangka dibawahnya. Hal ini sama seperti saat pengereman. Besarnya safety factor adalah 0,71.

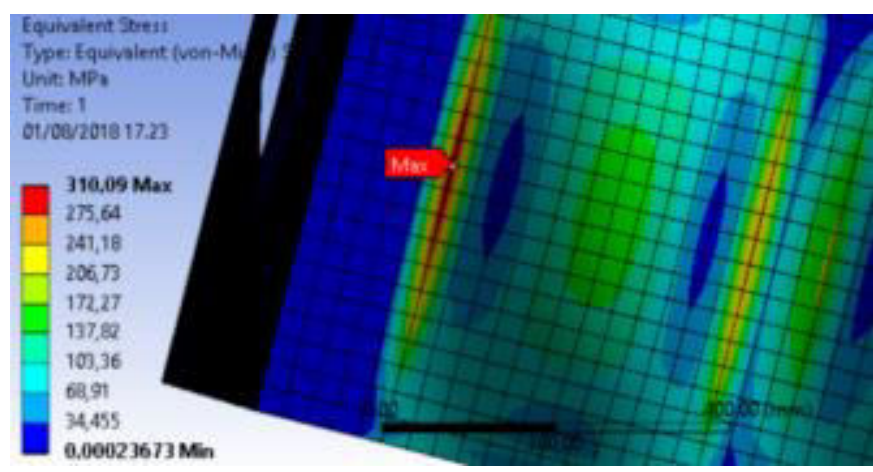

(a)

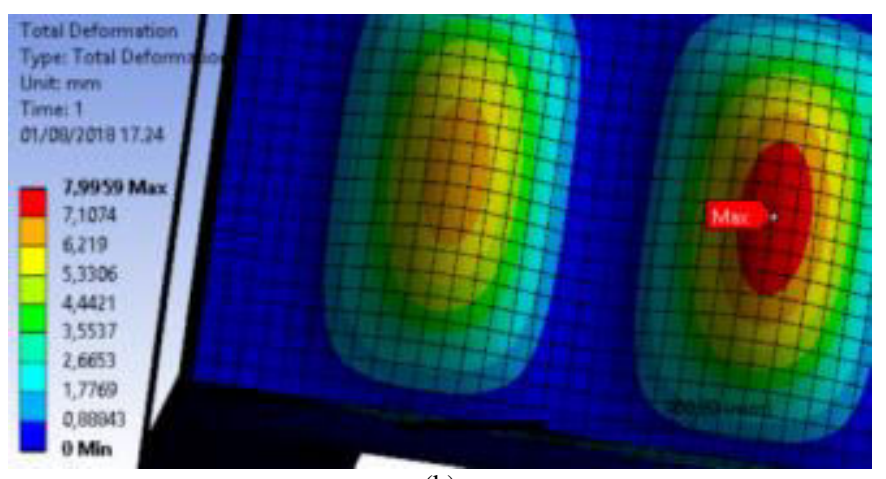

(b)

Gambar. 6. (a) Lokasi deformasi maksimum hasil tes konvergensi pada box body utuh pertama ketika mengalami pengereman dengan muatan penuh, (b)Tampilan detail deformasi maksimum.

\section{Hasil Analisis Pengereman Box Kedua}

Pada gambar 7.(a) menunjukkan hasil tegangan von misses sebesar 348,19 Mpa. Tegangan tersebut berada di part yang sama saat mengalami kondisi pengereman di box pertama. Gambar 7.(b) dengan skala 22 kali menunjukkan besar deformasi maksimum sebesar $8,0263 \mathrm{~mm}$ pada bagian seperti box pertama. Besarnya safety factor adalah 0,635.

\section{Hasil Analisis Belok Box Kedua}

Pada gambar 8.(a) menunjukkan hasil tegangan von misses sebesar 348,69 Mpa. Tegangan tersebut berada di part yang sama saat mengalami kondisi belok di box pertama. Gambar 8.(b) dengan skala 22 kali menunjukkan besar deformasi maksimum sebesar $8,0357 \mathrm{~mm}$ pada bagian dalam seperti pada box pertama. Besarnya safety factor adalah 0,633.

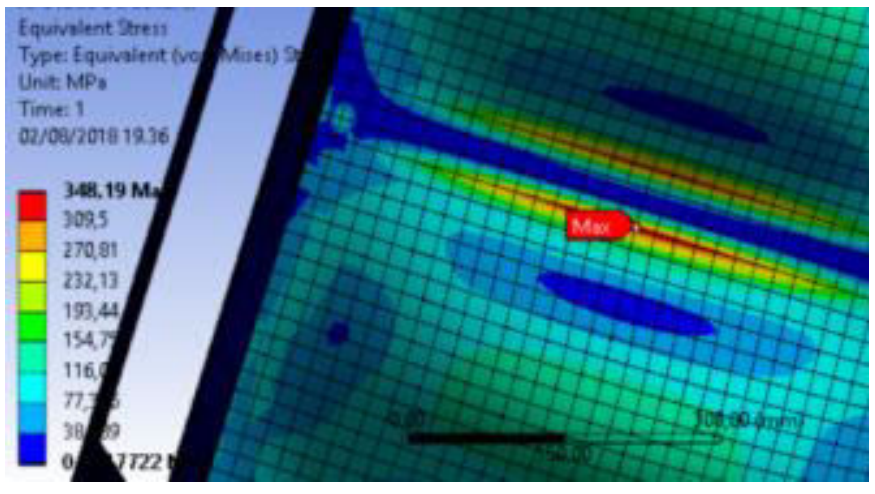

(a)

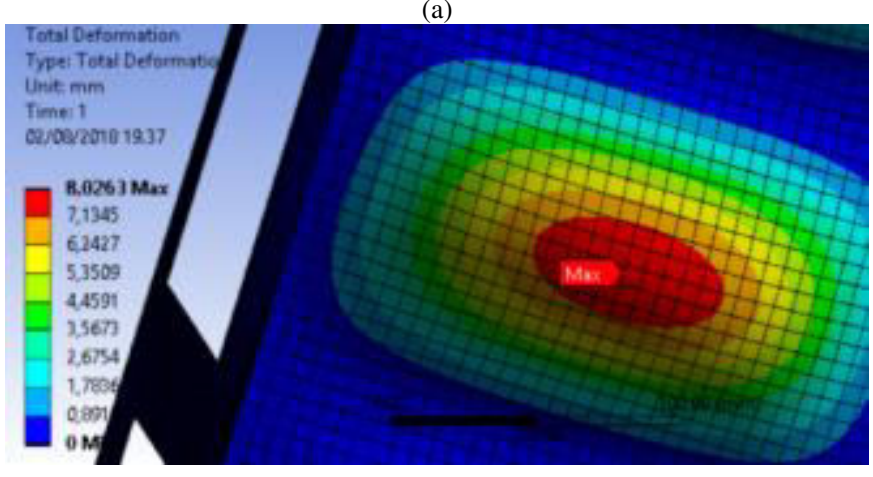

(b)

Gambar. 7. (a) Lokasi deformasi maksimum hasil tes konvergensi pada box body utuh kedua ketika mengalami pengereman dengan muatan penuh, (b)Tampilan deformasi maksimum.

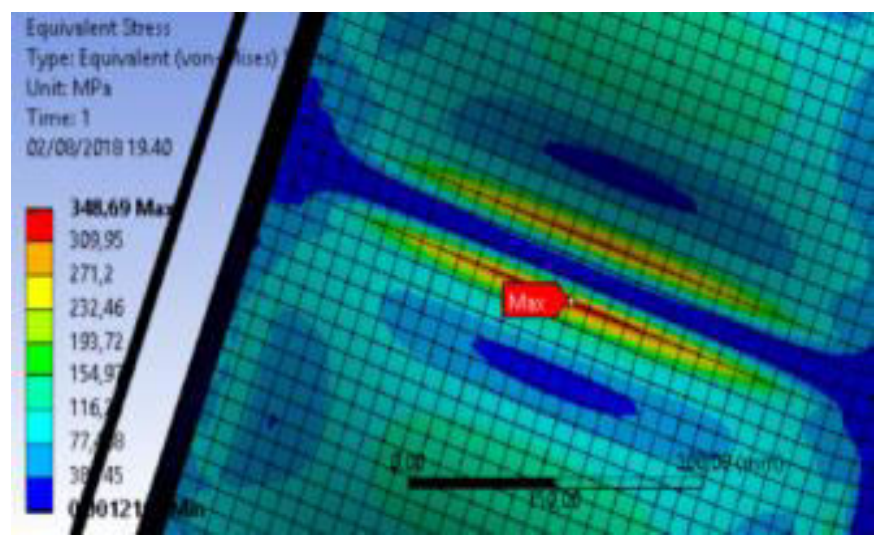

(a)

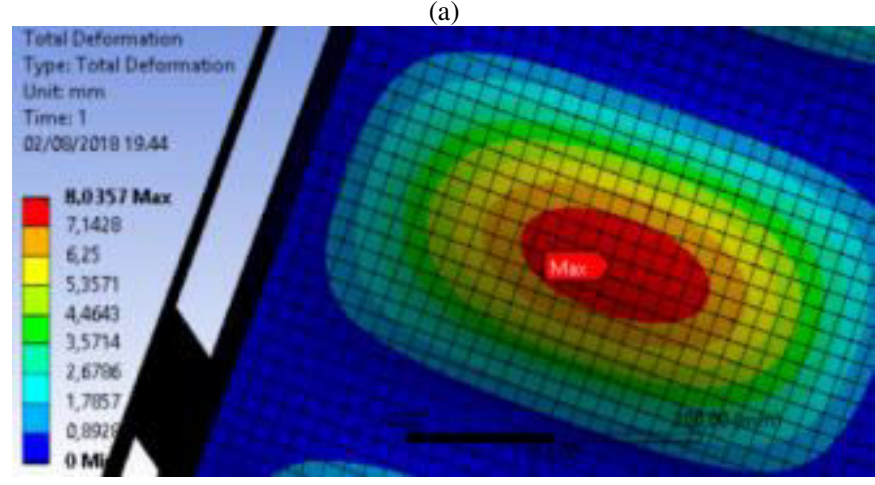

(b)

Gambar. 8. (a) Lokasi deformasi maksimum hasil tes konvergensi pada box body utuh kedua ketika mengalami belok dengan muatan penuh, (b)Tampilan 


\section{E. Model Re-design Box Ketiga}

Berdasarkan hipotesis yang dilakukan sebelumnya, bagian kerangka merupakan salah satu bagian dari box yang akan dilakukan re-design. Perubahan geometri pada bagian kerangka atas dilakukan guna mendapatkan massa yang lebih ringan dan lebih kuat. Perubahan terlihat pada gambar 9.

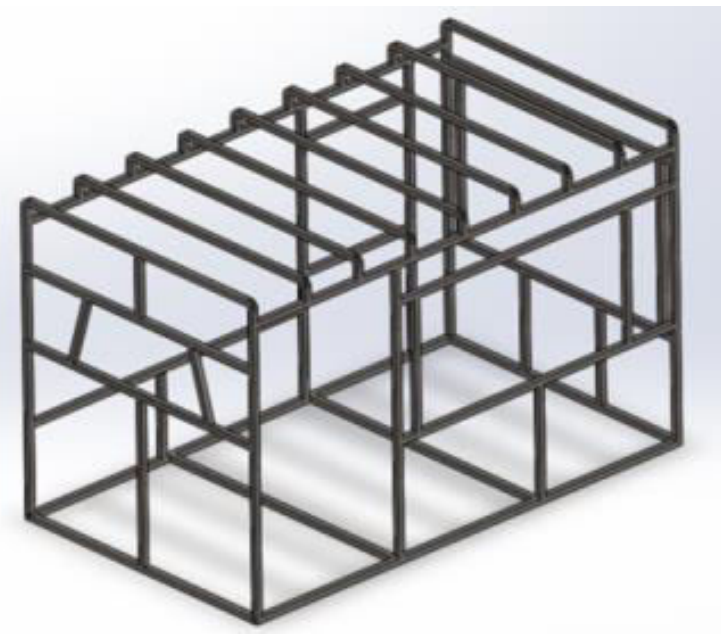

(a)

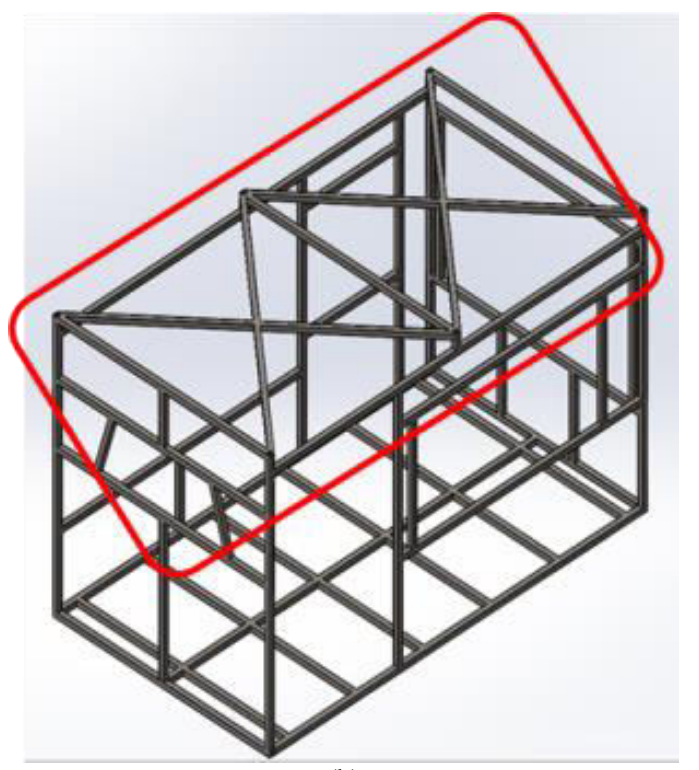

(b)

Gambar. 9. (a) Model kerangka pada box pertama dan kedua, (b)Model redesign kerangka pada box ketiga.

Bagian kedua yang dilakukan re-design adalah bagian dalam box. Pada bagian sisi pada bagian box dalam dilakukan penggantian material dari mild steel menjadi fiber glass. Pada bagian alas dari box dalam dilakukan perubahan dimensi ketebalan dari $2 \mathrm{~mm}$ menjadi $4 \mathrm{~mm}$ dengan material tetap sama seperti sebelumnya, yaitu mild steel. Hasil dari re-design keseluruhan box dilihat saat modelling berhasil menurunkan massa box menjadi $359 \mathrm{~kg}$.

\section{F. Hasil Analisis Re-design Box Ketiga}

Hasil analisis yang telah dilakukan pada box pertama dan kedua mendapatkan hasil yang masih tidak aman jika dihadapkan dengan kondisi muatan penuh saat berbelok dan pengereman. Oleh karena itu dilakukan re-design box ketiga dengan mengacu pada kondisi yang memiliki tegangan von misses terbesar, yaitu saat mobil kedua mengalami kondisi belok.

Gambar 10.(a) menunjukkan bagian box yang mengalami tegangan von misses maksimum. Tegangan tersebut berada di alas bawah dan alas atas box bagian dalam, namun hanya di salah satu ujung sisi dari alas saja, yaitu sebelah kanan box. Bagian tersebut yang berada di sebelah kanan karena box berbelok ke arah kanan. Hasil simulasi menunjukkan bahwa besar tegangan von misses sebesar 108,01 Mpa. Besarnya tegangan diarea tersebut menjadi maksimum disebabkan karenan beban muatan penuh yang besar sehingga tegangan terfokus pada area tersebut. Hal ini sama seperti pada box pertama dan kedua, namun hasil ini tidak sebesar hasil pada box pertama dan kedua. Besarnya safety factor adalah 2,04.
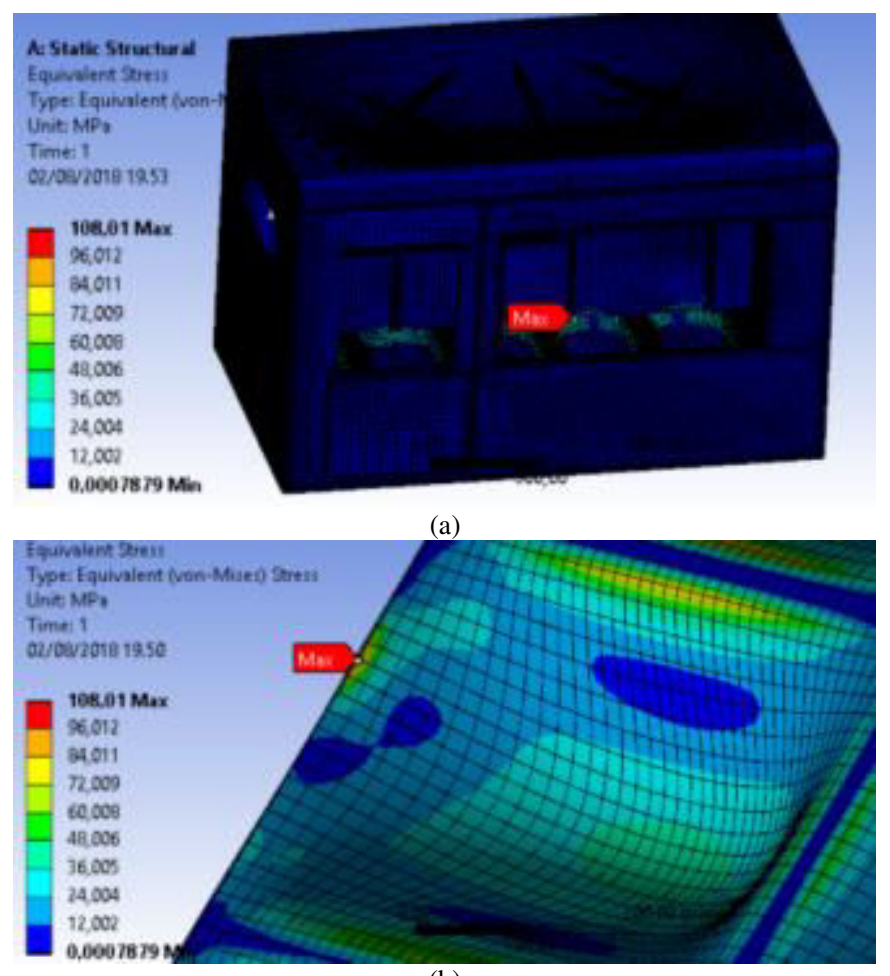

(b)

Gambar. 10. (a) Lokasi tegangan von misses maksimum hasil tes konvergensi pada box body utuh hasil re-design ketika mengalami belok dengan muatan penuh, (b)Tampilan tegangan von misses maksimum.

Gambar 11.(a) menunjukkan besar deformasi maksimum yang terjadi pada saat dilakukan pembebanan pengereman. Deformasi maksimum terjadi sebesar $1,0892 \mathrm{~mm}$ pada alas bawah box bagian dalam dimana bagian tersebut adalah bagian yang tidak mengalami kontak langsung dengan kerangka dibawahnya. Hal ini sesuai dengan besarnya beban muatan penuh yang dibebankan pada area tersebut. Nilai deformasi yang terjadi hanya $1,0892 \mathrm{~mm}$ tetapi pada gambar 11.(b) tampak cekungan yang besar dikarenakan adanya penggunaan skala deformasi sebesar 160 kali dari kondisi sesungguhnya. 


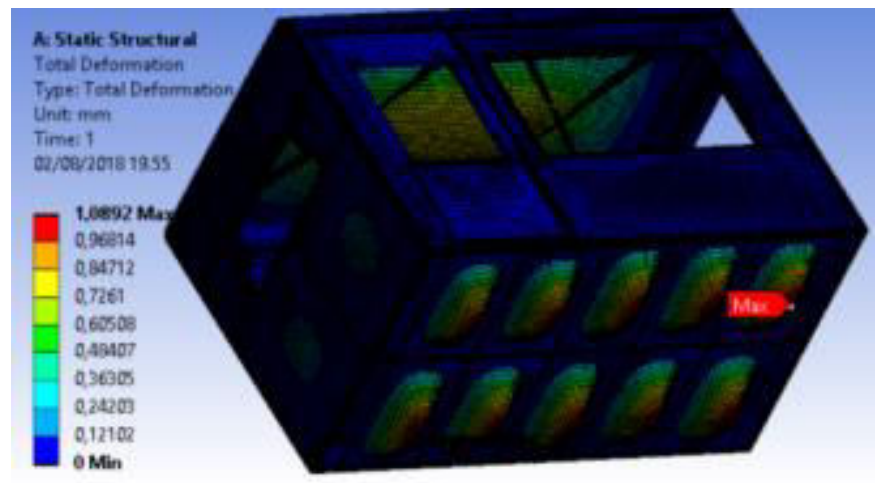

(a)

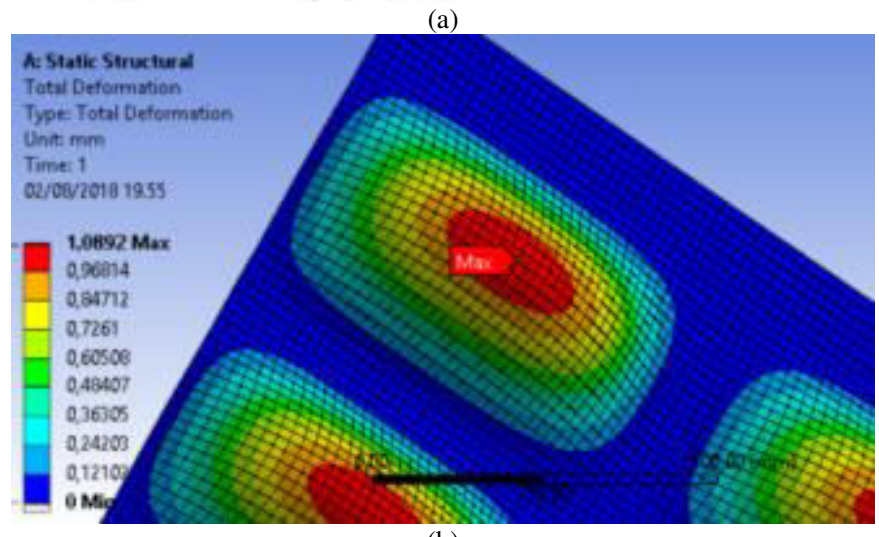

(b)

Gambar. 11. (a) Lokasi deformasi hasil tes konvergensi pada box body utuh hasil re-design ketika mengalami belok dengan muatan penuh, (b)Tampilan deformasi maksimum.

\section{KESIMPULAN DAN SARAN}

Fungsi analisis kekuatan dengan metode elemen hingga adalah untuk mengetahui sebesar kekuatan suatu desain dalam menghadapi kondisi pembebanan tertentu. Berdasarkan analisis pada penelitian ini diketahui bahwa perubahan geometri dan penggantian material dapat menghasilkan hasil yang lebih baik dari desain sebelumnya.

Hasil dari penelitian ini masih perlu untuk dilakukan penelitian lebih lanjut terutama untuk kegiatan meshing karena dapat mempengaruhi keakuratan hasil akhir. Perubahan jenis meshing dari solid menjadi shell akan lebih efisien. Penggunaan jenis elemen meshing hexagonal dengan persentase yang mendominasi akan mendaptkan hasil yang lebih akurat dan baik. Verifikasi juga dapat dilakukan dengan membandingkan hasil akhir dengan perangkat lunak lainnya yang sejenis agar didapatkan perbandingan.

\section{DAFTAR PUSTAKA}

[1] F. Adhim, "Analisis Struktural Performa Chassis Sapuangin Speed 2013," Surabaya, 2014.

[2] M. Ahmad, "Pengembangan Penyangga Box Mobil Pick-up Multiguna Pedesaan," Surabaya, 2014.

[3] A. Wiratama, "Analisa Kekuatan Chassis Bus Listrik menggunakan Simulasi Berbasis Metode Elemen Hingga," Surabaya, 2015.

[4] T. Gillespie, "Fundamental of Vehicle Dynamics," United Kingdom, 1992.

[5] D. Radyantho, "Pengembangan Body Dan Cabin Mobil Pick Up Multiguna Pedesaan,” Surabaya, 2014.

[6] NACTO, "Urban Street Design Guide : National of Association of City Transportation Officials,” 2012. [Online]. Available: https://nacto.org/publication/urban-street-design-guide/intersectiondesign-elements/corner-radii/. 